\title{
Pak RT is Our Hero
}

\author{
$1^{\text {st }}$ Lailatul Badriyah \\ Department of Social Studies \\ Universitas Negeri Surabaya \\ Surabaya,Indonesia \\ Email: lailabi17@gmail.com
}

\author{
$4^{\text {th }}$ Yosi Trisa \\ Department of Social Studies \\ Universitas Negeri Surabaya \\ Surabaya,Indonesia \\ Email: yosi.trisa@yahoo.com
}

\author{
$2^{\text {nd }}$ Sarmini \\ Department of Pancasila and \\ Citizenship Education \\ Universitas Negeri Surabaya \\ Surabaya, Indonesia \\ Email: sarmini@unesa.ac.id
}

\author{
$5^{\text {th }}$ Arif Rahman Muttaqien \\ Department of Social Studies \\ Universitas Negeri Surabaya \\ Surabaya,Indonesia \\ arrahmanlareosing@gmail.com
}

\author{
$3^{\text {rd }}$ Siti Dina Safrianti \\ Department of Social Studies \\ Universitas Negeri Surabaya \\ Surabaya,Indonesia \\ Email: dinaviolla99@gmail.com
}

\author{
$6^{\text {th }}$ Nur Fuad Zakiyatul Azizah \\ Department of Social Studies \\ Universitas Negeri Surabaya \\ Surabaya,Indonesia \\ Email: n.fuadzakiya@gmail.com
}

\begin{abstract}
Beggars become a social problem in Situbondo. Poverty is the main reason for begging. Not infrequently they settled on the streets because they do not have a place to stay. Based on the paradigm of the functional structure of the focus of research illustrates how beggars sought shelter and assistance in meeting the needs of infrastructure with the help of a Chairman RT. Data collected by using direct observation, interview, and documentation. Data analysis was performed with the pattern of Miles and Huberman interactive analysis with stages of data collection, data reduction, exposure of data, drawing conclusions and grounded in the perspective of Robert K. Merton's theory with the main concept of function, dysfunction, functions manifest and latent functions. The results showed that the role of $\mathrm{RT}$ in meeting the needs of infrastructure family of beggars who live in the complex Tuna work is as follows: 1) Ensuring family relocation of beggars are homeless on the government to get a place to live, 2) Implement policies to meet the needs of infrastructure family beggars easily, 3) Capitalized friendliness and humility to lure donors. The study recommends how efforts to address the problems arising from the presence of beggars in particular to ensure its survival in order to create a system that is balanced in society.
\end{abstract}

Keyword-Password Lock The role of Chairman of RT, Beggar Family Infrastructure, Works Tuna Complex.

\section{INTRODUCTION}

Beggars can be found in various places in the developed and developing countries, such as tourist spots but does not interfere with the activity of tourist visitors [1] [2], City center [3], worship place [4]And along the way [5], Terminal, patio stores, under a bridge, and the shopping center is a shelter and a place to beg for street children in Indonesia[6],

Several factors cause a person to beg. Poverty is a major factor[7], In addition to poverty, coercion of the family to be a factor for children to beg[8], Children are deliberately forced by their families to beg but they do not live on the streets[9], Factors religious, marital status, education level, rural or urban, work, and social class also influence the choice of a person to beg[10], According to beg family history factors, disability, death of father, family size, smoking, and drug abuse are also factors cause someone to beg [11],

The community has a diverse perspective on beggars. Begging, drinking in the street, and the homeless are considered as one of the problematic cultural and must be prevented existence of public space [12], The poor and marginalized who are in town often understood as those living in the worst shelter or even homeless. They labeled homeless, poor, and very poor. The worst conditions experienced by enabling them to perform their livelihoods in urban areas. This means potentially create urban slums[13], Begging can also be seen as a survival strategy of hunger, increase revenue when ill, unemployed or at a time of scarcity[14],

Some effort is required to tackle the problem of beggars. Holistic and effective policy coordination is needed in response to widespread social exclusion of people who beg[15], A large number of beggars seeking information to solve problems encountered during the begging, they depend on the phone but the tools especially illiteracy and lack of awareness about basic rights to information and information needs are the major difficulties faced beggar for accessing information [16], Some policies about the use of media charity box managed by the agency applied in various places for distribution of donations to beggars, is seen as more effective policies to channel donations to beggars but the management should be transparent and be responsible for the money received from donors as well as distribution[17],

Various studies have been conducted to assess the problem of beggars, As well as about the presence of beggars in various places [1], [2], [3], [4], [5], [6] and efforts to address the problem of beggars [15], [16], [17] but there is no explanation about how the efforts to overcome the need for facilities and infrastructure in the midst of economic limitations.

Using the structural-functional paradigm with the perspective of the theory of Robert K. Merton focus of this 
paper is to outline how where the role of RT in building infrastructure beggar families who live in the complex Tuna work as an alternative attempt to overcome the problem of the need for infrastructure beggar family.

\section{RESEARCH METHODS}

The research design is a case study. Based on the structural-functional paradigm of this research seeks to explain the role of RT in building infrastructure beggar families who live in the complex Works Tuna. The informants are Chairman RT RT / RW 03/24 complex Tuna Beggars work and staying at work is complex Tuna, Village Mimbaan District of Panji Situbondo. Data collected by using direct observation, interview, and documentation. Data analysis was performed with the pattern of Miles and Huberman interactive analysis with stages of data collection, data reduction, exposure data and drawing conclusions and perspectives grounded in the theory of Robert K. Merton with the main concept of function, dysfunction, functions manifest and latent functions as a knife analysis.

\section{RESULTS AND DISCUSSION}

Appropriate formulation of the problem, the following describes the role of the RT in meeting the needs of facilities and infrastructure needed by a family of beggars in Works Tuna complex.

\section{A. We Begging For Poor}

The beggars lived in various places in the city center Situbondo. They inhabit a doorway, terminals, markets, and streets in the city center Situbondo. They had come from the village to earn a fortune through begging. The presence of beggars in the city center was motivated by several factors. Poverty is a major factor, educational background and low skills are also a reason for them to come to town and beg. As beggars statement: Our family came from the village, we do not have anything or can not afford. We do not have the money to send our children. we also do not have a job. So, we had come to the city beginning to find a job, because we do not have the skills because the school is not the end we beg that our family could eat (Panud, 62 years).

Family beggars persist around the town of Situbondo, they do not return to the village because they do not have things that can be expected in the village such as housing, jobs, possessions, and family. The town center becomes the only hope of life for them. The existence of beggars around the city center as homeless. We came with our family (wife and children) to the city, because the village does not have anything. Our family lived in the vicinity of the terminal, there are also other kelarga who lived at the corner market. We stay here as our life expectancy, because the village is not having any. We could not afford to buy a house, so we stay anywhere that can be used as a bed if night. We worked all day as a beggar. The money that we can only get to eat. We continue to beg so that every day can eat. We were really poor.
They (beggars) involving all members of their family (wife and children) to beg. The needs of the high life in the midst of poverty forcing their family members also beg that their basic needs are met.

Me, my wife and children are also begging. We all need to eat, all also beg that our basic needs are met. If only I beg, my income is less to meet the food needs of all family members.

Based on the structural analysis as proposed by Robert K. Merton that all elements or elements of community life should function or function so that society as a whole can function properly [19], Various efforts are needed to tackle the problem of the presence of beggars, especially homeless beggars who are in Situbondo. The involvement of various parties, especially the government became a very important element to seek solutions to problems arising from the existence of a homeless beggar.

\section{B. We Disturbing Presence Urban Spatial}

The presence of family beggars around the city such as terminals, markets, a doorway, and the streets cause social problems. Their presence is considered disturbing the beauty of the surroundings. Appearance and slum dwellings cause a negative response from the public. As the narrative Panud (62 years):

We were driven by the shops if sleeping in front of him. Perhaps they were distracted because we really rundown and does not have a place to stay. Our appearance and our goods are considered disturbing scene.

A similar statement was stated by Agus (50 years old):

Terminal clerk warned us not sleep around terminals because they interfere with people passing by and of course cleanliness around the terminal. But we had no choice because they have no place to stay.

From here Merton developed the idea of dysfunction. When the structure and function may contribute to the maintenance of the social system but can contain negative consequences on other parts[19], This can be exemplified in the existence of a family of beggars who live in the market area, a terminal, a doorway can make a positive contribution to the communities living in the area of the market to provide a place to stay for free and can accommodate their family, but the circumstances such as these can contain negative consequences for the community around the market, terminal, or doorway bothered by the presence of the families of beggars. The idea of non-functioning were raised by Merton. Merton argued nonfungsi as a consequence is not relevant for the system.

C. The presence of A Hero, Now We Have A Small Instana The presence of family beggars tuna wiswa around the market, terminal and shop-fronts can not be ignored again. The Government has the primary responsibility to address the problem. Seek shelter and ensure their needs. Family homeless beggars expect solutions from the government. Some authorities, Local Government, and Social Service seeks to address the problem. Sunyoto (58 years) said:

My family and other beggars asking for a solution, we are the government's expectations. We think the 
government is responsible to the state of poor people like us. Finally, at that time (1991), having held carnival teenagers in Situbondo who attended Sister Tutut (daughter of President Suharto) in cooperation with Regent Sudaryanto and Social Service provide land in the mountains piggir the city as a place of residence for a family of beggars in order to not make the shanty town. We have to cut down forests in the mountains and the government built los room. Until now the complex is known as Tuna complex work.

Sunyoto (58 years old) family coordinator beggars unanimously elected chairman Tuna Complex RT at work. Decision citizens voted Sunyoto as the RT is based on several considerations. It is a wise and caring for others are strong reasons for a family of beggars to make it as head of RT. As the narrative Agus:

We all agreed Mr. Sunyoto as Chairman of RT here, because from the outset he actively fought for our rights as homeless in order to get a place to stay.

In line with the narrative Agus, Panud continued:

We often deal with the government or if there are problems that menengahinya Sunyoto fellow beggar. He who represent our aspirations to the government that we no longer live in the markets, terminals and streets.

Facilities and infrastructure beggar family residence in the complex opened Tuna work at the beginning of a very minimal and far from decent. Los building should be a place to live together with the other beggars family. Meeting the needs for facilities and other infrastructure is very important to ensure the survival of the family of beggars.

Relocation of residence beggars Works Tuna complex to create new problems. The lack of facilities and infrastructure in Tuna complex work requiring treatment very seriously. As the narrative Heny (38 th), one of the residents Tuna complex work:

More and more family members increases, sometimes there are relatives who come here later settled and married couples beggar who gave birth or got a new baby. Los previous building built by the government were insufficient. The existence of the systems are also limited.

Based on that data, from the viewpoint of the juridical in Article 34 paragraph (1) of the 1945 Constitution states "The poor and neglected children maintained by the state. Based on the sound of that article in the basic law of Indonesia, the country has a huge responsibility to maintain the poor and abandoned children. In this study families homeless beggars are part of the poor in Situbondo. Family relocation solutions beggars from the city center, streets, shop-fronts Tuna complex to work undertaken by the local government in cooperation with the central government is mandated by the article is to be implemented.

Family beggar who lived in Tuna complex work requires infrastructure to meet the needs of his family. Financial constraints become obstacles in meeting those needs. Head of RT implement policies as a result of consultation with the family of beggars as citizens in Tuna complex work to meet those needs with ease. The shape of these policies include:
1) Providing installment purchase of materials establishment of semi-permanent house as a residence.

Head of RT seeks to provide convenience to the family of beggars in the form of installment purchase establish a semi-permanent home as a residence for his family. As the narrative Hardi (40 years old):

Results of begging paid to the Chairman of the RT. Money is being managed to buy materials to build semi-permanent home such as bamboo, wood mast, "bidhik" (bamboo matting on the walls in Madurese), precarious and so forth.

Likewise submitted by Heny:

Initially we had to pay $R p 250,000$ to get the ingredients establishment of houses, then we installments to the Chairman of $R T$ every day $R p$. 5000 to pay it off.

2) Lighting distribution (electric) collective

In addition to shelter, the family of beggars also require light illumination for homes, especially at night. Collective illumination distribution made by the Chairman of RT in order to offset the cost of installation. As the narrative Hardi:

To deliver electricity to homes, residents of the home using power line with a capacity of Chairman of RT 1300 watts and from the child's home he (Sukartina) with a capacity of 900 watts.

Regarding the system of payment / billing electricity consumption costs, Heny (residents) said:

Depending on the amount of light bulb used in the home and use of goods connected with electricity. If only some lights are used expenses to be paid only about $30 \mathrm{rb}$. If coupled with a fan or tv burden to be paid could reach $60 \mathrm{rb}$.

3) Providing installment payment for the purchase of household appliances needs.

Head of RT to provide relief by providing installment payment for a family of beggars to buy household needs. As where the narrative Agus:

Our family (beggars) kan also need household appliances. If buying directly'm not capable. So the head of $R T$ presents goods alleviated family payment by installments. Such as plastic wardrobe, stove, ceiling fan, TV and so forth.

\section{4) Channeling collective taps}

The need is no less important for the families of beggars in Tuna complex work is the need for access to clean water. The family of beggars in need of clean water for everyday purposes ranging needs of drinking, cooking, bathing, washing and so forth. Head of RT install taps collectively distribution to alleviate the need for a beggar families will access to clean water. As the narrative Chairman RT:

On the right mountain difficult to make a well. The most basic water needs for drinking, cooking, 
bathing, washing and others. The water here is channeled through the taps which I coordinate. They, beggar families each household only pay Rp 20,000 per month to Me. They are free to use water according to their needs.

Begging is a major job to make ends meet. However, the head of the family who still have a strong physical effort and also seeks to earn a fortune by being a traditional rickshaw drivers. Some of the traditional rickshaw units owned by the Chairman of the Special RT leased to a family of beggars as citizens of Tuna Complex Work. as the narrative

Head of $R T$ rent a rickshaw to our ablebodied, we just deposit money daily rental $R p$. 2000 to the head of the neighborhood as the owner of the rickshaw.

The role of RT in seeking fulfillment of needs for infrastructure beggar family in the Tuna Complex work received a positive response from a family of beggars. Policies and the form of care given to a family of beggars as their citizens have been helpful in the survival of the family of beggars. In the midst of financial constraints they are still able to survive in meeting their needs. As the narrative Hardi:

We are very grateful to have my own place so that our family's privacy is maintained. Relief materials for house purchase are applied by Head of RT extremely helpful to us who are financially not able to directly make a home.

Another narrative delivered by Heny, a huge benefit felt by his family:

We also want to live decent as they are able, household appliances to ensure the survival of our everyday also needed. The credit system applied by the Chairman of RT very helpful to us. Likewise, such as lighting and access to clean water, even if we were beggars also deserve it like society in general. Mild payment system is very helpful in the midst of our economic limitations.

The presence of a head of RT wise in the midst of a family of beggars is like a hero for their lives. The role of Chairman of RT has changed family circumstances of homeless beggars now a beggar families who have a place to stay though far from luxurious. Based on the concept of function in the theory of Robert K. Merton defined as the consequences are realized and that creates adaptation or adjustment of the social system. Based on that data in an effort to meet the needs of RT infrastructure beggar family in Works Tuna complex containing positive consequences for the family of beggars.

Spirit of mutual cooperation and high in complex kinship Tuna work is very visible. This is because the beggar families living in Tuna complex work is coming from the same background and the same condition. Deliberation is preferred in Tuna complex work is that the problems facing the residents easily resolved and avoid conflict. It became a special feature on a family of beggars who live in the complex Works Tuna.

D. Hospitality, Humility as Capital to Attract sympathy Individual Donors, Foundations, and Kader Political Party

Works Tuna complex family complex dubbed beggars by the surrounding community. RT and family of beggars in Tuna complex work is not offended by the nickname even those friendly to the guests, they recognize and realize where they actually are making the activity of begging as a job. As the narrative of one of the residents:

All citizens who beg to admit his job, because we are a people who can not afford and could only beg. If there are guests such as donors and you, for example, ask about our research for the benefit of beggars we certainly welcome to attend and give information in real terms (Heny, 38 Years).

As Chairman of RT establish good relationships with others, especially the donor is very important. The need for infrastructure is higher in the midst of limitation, a helping hand from the donors into one solution. Friendly welcome every donor and humble is a resource for the Chairman of RT to lure donors. As the narrative Chairman RT:

Some donors from the community around Situbondo individually been repeatedly come to this complex to give donations such as logistics, stationeries, and used clothes. We were warmly welcomed and very grateful. If donations of money then I announce to the citizens face and used the money to the common interest such as the maintenance of public facilities if there is damage.

Donors who come to Tuna complex work is not merely an individual but there are institutions such as foundations engaged in special social donations in the form of the surgical house. Establishment of good relations between the head of RT and donors appealed to other donors such as the one foundation. As the narrative RT:

One of the donors never tell in this complex situation to a friend who has a foundation that most of the complex is comprised of a family of beggars and incapable. I still remember the name of the foundation is the Foundation Habibillah provide semi-permanent housing assistance for elderly beggar families whose homes were not habitable(Sunyoto 58 years).

In addition to individual donors and foundations, Chairman of RT friendly welcome donors on behalf of the cadres of any political party. For the head of RT establish relationships with a cadre of political parties solely for the benefit of donation. As the narrative Chairman RT:

One political party cadres to offer assistance in this complex, I thank tailored to the needs. But I submit that such assistance should not be based merely interest donations to political interests. He also approved

Important role as Chairman of RT is to be sensitive to the problems faced by citizens. Family beggars who live in the complex work of all religious Muslim Tuna. They need places of worship along with supporting the activities of worship. The agreement of the Chairman of the RT and the donor of the political party cadres are realized into mushollah assistance.

Works Tuna villagers all Muslims. We need places of worship together because in this complex mushollah yet. 
Help from my political party cadres embodied into mushollah.

The presence of donors for the family of beggars is expected. A little more help given will provide a huge benefit for a family of beggars in Tuna complex work because it can help meet their needs in the midst of economic limitations.

Based on the concept of latent function as Robert $\mathrm{K}$. Merton defined as functions that are not expected (nonintended). Based on the data above the efforts of RT is limited to how to meet the needs of infrastructure family of beggars in the complex Tuna work, more than it takes effort to be the provision of skills training for the beggars of childbearing age for the activities of beggars minimized and switch to a more decent job according to ability has. This relates to improving standards of living, especially beggars so as not merely rely on the mercy of others.

\section{CONCLUSION}

The results showed that the role of RT in meeting the needs of infrastructure family of beggars who live in the complex Tuna work is as follows: 1) Ensuring family relocation of beggars are homeless on the government to get a place to live, 2) Implement policies to meet the needs of infrastructure family beggars easily, 3) Capitalized friendliness and humility to lure donors. The study recommends how efforts to address the problems arising from the presence of beggars in particular to ensure its survival in order to create a system that is balanced in society.

\section{ACKNOWLEDGMENT}

Gratitude researchers prayed to Allah for all his power has given to researchers in growing kepampuan learning initiative, conduct research to solve it. Researchers realized all things would not have been possible without power. Acknowledgments researcher goes to those who have helped in the completion of this study in particular to Prof. Dr. Sarmini as pengampu Course Studies Social Affairs on best contributions provide a deep understanding of social problems, especially in the study the researchers did. Best motivation, spirit energy source for researchers at every meeting guidance, to better conduct research. Head of RT RT / 03 / RW 24, Village Mimbaan district. Panji Situbondo Mr. Sunyoto and his daughter Ms. Heny (request for designation) as the informants in this study. With patience and hospitality in providing information that researchers need for research.

\section{REFERENCES}

[1] G. Qiao, N. Chen, and B. Prideaux, "Understanding interactions between beggars and international tourists: the case of China," Asia Pacific J. Tour. Res., Vol. 22, no. 3, pp. 272-283, 2017.

[2] K. Andriotis, "Beggars-tourists' interactions: An unobtrusive typological approach," Tour. Manag., Vol. 52, pp. 64-73, 2015.

[3] C. Sociological, "Ian McIntosh and Angus Erskine (2000) '" Money for nothing "Understanding ?: Giving to Beggars," "vol. 5, no. 1, pp. $1-14,2000$.

[4] AM Conservation and M. Maniati, "Beggars are sometimes the choosers !," Discourse Soc., Vol. 21, no. 1, pp. 41-57, 2010.

[5] T. Abebe, "Earning a living on the margins: Begging, street work and the socio-spatial experiences of children in addis ababa" Geogr. Ann. Ser. B Hum. Geogr., Vol. 90, no. 3, pp. 271-284, 2008.

[6] A. Demartoto, "Need-based management of street children in Surakarta city of central Java province of Indonesia," Asian Soc. Sci., Vol. 8, no. 11, pp. 107-118, 2012.

[7] R. Chen and C. Li, "Relief and Control: Analysis of Countermeasures for Urban vagrants and beggars," vol. 6, no. 3, pp. 128-131.

[8] A. Judge, "Social, Biology and Economic Life of Children Links on Street-Begging in Bangladesh: A Cross-Cultural Multivariate Analysis," vol. 3, no. 1, pp. 12-19, 2017.

[9] J. Ballet, A. BHUKUTH, F. Rakotonirinjanahary, and M. Rakotonirinjanahary, "Les enfants mendiants à Antananarivo: Quelles logiques familiales sont à l'œuvre?" Population (Paris)., Vol. 65 (4), pp. 801-820, 2010.

[10] H. Ahmadi, "A study of beggars characteristics and attitude of people towards the phenomenon of begging in the city of Shiraz," J. Appl. Sociol., Vol. 39, pp. 135-148, 2010.

[11] C. Factors, "Factors Contributing to Child Begging in Hilla CityBabylon- Iraq during the Year 2011," vol. 2013, no. 3, pp. 195199, 2013.

[12] S. Johnsen and S. Fitzpatrick, "Revanchist sanitisation or coercive care? The use of enforcement to combat begging, street drinking and rough sleeping in England," Urban Stud., Vol. 47, no. 8, pp. 1703-1723, 2010

[13] D. Jackman, "Are 'the destitute' destitute? Understanding microinequalities through the concept of defiled surpluses, " Environ. Urban., Vol. 29, no. 1, pp. 251-266, 2017.

[14] C. Ferguson, "The Political Economy of the Street and its Discontents," Cult. Soc. Hist., Vol. 12, no. 1, pp. 27-50, 2015.

[15] C. Kennedy and S. Fitzpatrick, "Begging, rough sleeping and social exclusion: Implications for social policy," Urban Stud., Vol. 38, no. 11, pp. 2001-2016, 2001.

[16] E. Mansour, "An explanatory study into the information-seeking behavior of Egyptian beggars," J. Librariansh. Inf. Sci., Vol. 49, no. 1, pp. 91-106, 2017.

[17] C. Pérez-Muñoz, "beneficence, Street Begging, and diverted Giving Schemes," Polit. Res. Q., P. 106591291876803, 2018.

[18] Bernard Raho, Modern Sociological Theory, Jakarta: Achievements Library Publishers, 2013.

[19] George Ritzer, Sociology of Science paradigm Ganda, Jakarta: King Grafindo Persada, 2013. 